\title{
Immigration and Its Impact on Hawaii's Racial Composition: 1971 to 2000
}

\author{
Xuanning $\mathrm{Fu}^{*}$
}

Department of Sociology, California State University, Frenso, Fresno, CA 93740, 1-559-27803020, USA

\begin{abstract}
Hawaii is one of the most racially diverse places in the world, with many racial groups of relatively small sizes. The indigenous people, Hawaiians, have experienced a very high rate of intermarriage in the past few decades. Although high outmarriage is common among all groups, Hawaiians are unique in two characteristics. First, they do not have outside sources to replenish their ethnic stock like most other groups in the islands. Secondly, outmarried Hawaiians tend to have higher socio-economic status than inmarried Hawaiians. Consequentially, the number of native Hawaiians will inevitably decrease and have lower family socio-economic status at the same time. This paper examines the theme that changing definition of a Hawaiian is historically related to immigration of Pacific Islanders from many Pacific islands, and the trend continues today. The contemporary Pacific Islander immigrants who settled in Hawaiian from 1971 to 2000 made a small contribution to Hawaii's racial profile, but they tend to have lower education and occupational status when compared to immigrants to come from other parts of the world. The study concludes that although Hawaiians were originated from immigration, the current trend will not significantly change their demographic and socio-economic status quo.
\end{abstract}

\section{IMMIGRATION AND ITS POTENTIAL IMPACT ON HAWAII'S RACIAL COMPOSITION: 1971 to 2000}

Hawaii is one of the most racially and ethnically diverse places in the world, marked not only by many different racial and ethnic groups but also by a large scale of inter-group marriage between them. This uniqueness has helped promoting relatively harmonious racial relations in the islands, which in turn have made intermarriage a norm rather than an exception [1].

However, generations of high intermarriage also diluted the racial and ethnic identities of Hawaiians, and blurred the line between what is commonly referred to as PartHawaiians and Native Hawaiians. Since Native Hawaiians originally migrated from various Pacific Islands to Hawaii some 1500 years ago, immigration to Hawaii today from these same islands will likely be the only outside source to maintain Hawaii's indigenous racial and ethnic identity.

In this paper, I raise a research thesis that the Hawaiian identity is characterized by change, inclusiveness and selfidentification. To support this thesis, I examine the extent of legal immigration to Hawaii from 1971 to 2000, and analyze its potential impact on Hawaii's racial composition and the socio-economic well being of future generation Hawaiians and other Pacific Islanders in the state. The history of Hawaii and the history of immigration to the U.S. will be briefly introduced, and these two discussions will be bridged with the effect of immigration on Hawaii and its people. Data analysis will be based on INS data and Hawaii demographic data.

*Address correspondence to this author at the Department of Sociology, California State University, Frenso, Fresno, CA 93740, 1-559-27803020, USA; E-mail: xfu@csufresno.edu

\section{A BRIEF HISTORY OF THE HAWAII ISLANDS AND HAWAIIANS}

The Hawaii islands are located in the eastern half of the North Pacific, formed of seven major inhabited islands: Oahu, Hawaii, Maui, Kauai, Molokai, Lanai, and Nihau. The state population in 2000 is about 1.21 million, with $6.6 \%$ categorized as Hawaiians [2].

The history of Native Hawaiians and of Hawaii in general can be classified into four major periods: antiquity, monarchy, colonial and statehood, traced back at least 1,500 to 1,700 years when Polynesians from the Marquesas Islands and Tahiti came to live in the Hawaiian islands and became the first Hawaiians, or Kanaka māoli [3]. The Hawaiian language bears a close resemblance to Tahitian, Samoan, Tongan and New Zealand Maori languages, indicating a common cultural root among people of these islands. Hawaiians also share similarities with Tahitians and other central Polynesians in their physical features, traditions, and artifacts such as fishhooks, adzes, and ornaments [1, 3, 4].

Hawaiians had their first encounter with European sailors in 1778, and foreign settlers from England, America, Ireland, Portugal and China gradually arrived [3, 4]. Foreign population remained very small till around 1850, when nonHawaiians kept growing while the number of Native Hawaiians sharply decreased, due to diseases brought to the islands. The idea of strengthening the Hawaiian racial stock by bringing in immigrants from other Polynesian islands was advocated, but without much success $[3,4]$.

In the latter half of the $19^{\text {th }}$ century, sugar plantations became the most important island economy and it employed more than half of the Hawaiian male laborers. Labor shortage became acute and the Hawaii Kingdom started to attract large numbers of immigrant laborers from abroad. By 1890 , the census reported a total Hawaii population about 90,000, 
with 41,000 Hawaiians, 15,000 Chinese, 12,000 Japanese, 9,000 Portuguese, 2,000 Americans, 1,300 British and 1,000 Germans [3-5]. From that time on, Hawaii became more and more racially diverse. By 2000 , the resident population $(1,211,537)$ was 16.5 times its size in $1853(73,138)$ when the first census was conducted, and 7.9 times its size in 1900 $(154,001)$. This dramatic increase, however, is primarily outside the indigenous Hawaiian race.

Native Hawaiians. In Hawaii, the term Native Hawaiians usually refers to descendants of indigenous Hawaiians without a family history of extensive intermarriage, while the term Part-Hawaiians refers to individuals who identify themselves as Hawaiians but with a multi-racial family background. These two terms and their differences are mainly an issue of self-identification rather than a categorical distinction [1, 6]. Identifying Hawaiian subgroups has become a delicate issue even among Native Hawaiians, and different government agencies have different methods of classifying Native Hawaiians. For example, Hawaii State Department of Hawaiian Homelands are legally bound by trusts to provide services only to Hawaiians claiming over $50 \%$ ancestry dating back to antiquity. According to the Hawaii Revised Statutes, Section 10-2 (http://www.capitol. Hawaii.gov/hrscurrent/Vol01_Ch0001-0042F/HRS0010/ HRS_0010-0002.htm), Hawaiian are defined as descendants of the aboriginal peoples inhabiting the Hawaiian Islands who exercised sovereignty and subsisted in the Hawaiian Islands in 1778, and thereafter have continued to reside in Hawaii. It's important to note that this definition refers to "aboriginal peoples", not "people", suggesting that Native Hawaiians came from multiple origins in the first place.

Within this definition, Hawaiians are sub-classified into two major groups: Native Hawaiians consist of the population who claim over $50 \%$ ancestry dating back to antiquity, and Part Hawaiians who claim less than $50 \%$ of ancestry dating back to antiquity. Informally, these definitions and their differences are often blurred. Many who self-identify as Native Hawaiians do have a multiple racial family history although it is perhaps less extensive than that of a PartHawaiian.

There are various estimates of the indigenous population in Hawaii at the time when Europeans first "discovered" the islands in 1778, ranging from 200,000 to one million [4, 7]. Within the next 50 years $(1778-1828)$, the size of the Native Hawaiian population decreased by 40 to 65 percent due to diseases brought to the islands by foreigners. The indigenous population gradually became a small fraction among Hawaii's ethnic stocks, and in 1878, during King Kalakaua's reign, there were fewer than 58,000 Hawaiians alive. The number of full-blooded Hawaiians was further reduced to 30,000 by 1900 , due to high mortality, sterility (caused by sexually transmitted diseases), out-migration and intermarriage [4]. The low fertility for Hawaiians at that time was in sharp contrast to the overall high fertility among most other racial groups, although the trend was reversed in the latter half of the $20^{\text {th }}$ century [8]. By 1990 the state official count of full-blooded Hawaiians was 8,711 , only $0.8 \%$ of the state population [1,9]. In 2000, Native Hawaiians were counted at 10,858 , less than $0.9 \%$ of the total state population. Even so, many scholars have argued that the number of Native Hawaiians could be overestimated, because Part-Hawaiians were often counted as Native Hawaiians [1].

Native Hawaiians have had the highest rate of outmarriage among the island populations, reaching over $80 \%$ annually $[1,10]$. With about just ten thousand Native Hawaiians in the islands, ingroup marriage has become increasingly difficult for both social and biological reasons. Socially Native Hawaiians are surrounded by non-Hawaiians so that the chances of dating and marrying someone of non-Hawaiian ancestry are very high. Biologically Native Hawaiians tend to be somewhat related to each other and choosing a suitable mate is not easy.

Part-Hawaiians. In the past two hundred years Native Hawaiians have intermarried with people of many different racial origins. Most Hawaiians (according to the U.S. census) today are Part-Hawaiians. In 1853 the census showed 983 Part-Hawaiians (referred to at that time in the census as "half-natives") and the number increased only slowly in the next half century, due to a social stigma towards interracial marriage and the resulting inaccurate count of who were Part-Hawaiian [11]. By 1900 there were 7,857 PartHawaiians on record [1]. In the 20th century, the definition and categorization of Part-Hawaiians has changed several times in the census data. The 1910 and 1930 censuses differentiated between "Caucasian-Hawaiians" and "AsiaticHawaiians", but in the 1940, 1950 and 1960 censuses the category "Part-Hawaiian" was adopted [1]. The distinction between Native Hawaiians and Part-Hawaiians, however, was no longer made in the 1970, 1980 and 1990 censuses, largely due to the fact that there were very few full-blooded Hawaiians. The term "Hawaiians" in these three censuses combined Native Hawaiians and Part-Hawaiians. The state of Hawaii, on the other hand, continued distinguishing the two groups using a data collection method different from that of the U.S. Bureau of Census, resulting in a large discrepancy between the two systems. For example, in 1990 the state estimated 196,367 Part-Hawaiians, $18.0 \%$ of the state total, while the U.S. census counted 138,742 (both Native and Part-Hawaiians), $12.5 \%$ of the state total $[9,12]$. In 2000, the Census recorded 113,539 Native Hawaiians and other Pacific islanders reporting one race, and 282,667 reporting multiple races [10]. For the same year, the Hawaii State gave many different estimates on how many resident PartHawaiians the state has, depending upon how they were counted. These estimates vary from a low of $18 \%$ of the state population to about $22 \%$ [9].

Much of this discrepancy was caused by different definitions of race, and the Part-Hawaiian identity is by far the most difficult to define. The current practice by the Census Bureau to define a "Native Hawaiian" is similar to that of a "Native American" on the mainland, namely, 50\% or more of aboriginal ancestry of the land. However, there is no criterion to define a Part-Hawaiian except self-identification. Historically, both definitions, either self-given or defined by social institutes, have gradually changed. Take the Kamehameha School enrollment criteria (a private school system 
for Hawaiian children only) ${ }^{1}$ for example, the racial origins of enrolled students in the past 60 years have clearly changed. In $1929,78.40 \%$ of the students had at least onehalf Hawaiian blood (therefore they could qualify as Native Hawaiians using today's Census and Hawaii state definition). By 1992-93 enrolled students with 50\% of more Hawaiian blood were just $16.41 \%$ of the total studentbody, and the majority of the students $(65.57 \%)$ have only $1 / 4$ or less Hawaiian blood [13].

Like Native Hawaiians, Part-Hawaiians have had a very high rate of outmarriage. The majority of Part-Hawaiians have married out in the past few decades, making the Hawaiian identify increasingly inclusive over time.

\section{A BRIEF ACCOUNT OF IMMIGRATION TO THE UNITED STATES}

America is a nation of immigrants, and immigration to America could at least be traced back to the early 1600 s with the arrival of the original 110 pilgrims [14]. U.S. immigration has had a clear pattern of four waves, generally referred to as colonization wave (1600-1820), frontier expansion wave (1820-1870), industrialization wave (1880-1925) and globalization wave $\left(1965\right.$ - present). ${ }^{2}$ Associated with these waves are the changing patterns of originating nations and racial background of the immigrants (Bean et al. 2004). The first wave had immigrants from England and North-Western Europe, who later brought in Africans as slaves. The second wave immigrants were primarily from northwestern Europe, particularly from England, Ireland, and Germany, with a small number from Mexico and Asia [14]. The third wave lasted well into the $20^{\text {th }}$ century, and was characterized by a gradual shift to Southern, Eastern Europe and Asia as the main source of immigrants [15]. The fourth wave, which is not ending yet, largely saw immigrants coming from Mexico, Latin America, Asia, and the Pacific Islands [16].

The four waves were incrementally larger in size, with the fourth one estimated at 26.4 million by the end of the $20^{\text {th }}$ century. Just within one decade of the 1990s, the U.S. foreign-born population increased by $57 \%$ to reach 31 million in 2000. No other nation in the world has an immigration population of this size. The current fourth wave of immigration is expected to continue, leading to an increasingly diverse U.S. society but at the same time blurring racial and ethnic lines among the current generation. Immigration is also expected to help increase in the population of the United States, estimated at 400 million by 2050 [14, 16,17].

Socio-economically, immigrants generally have lower educational attainment than the native-born Americans, and they are also more likely to be employed in manual labor occupations, especially among those who have fewer than 4

\footnotetext{
${ }^{1}$ The Kamehameha Schools were founded under the will of Bernice Pauahi (Mrs. Charles R. Bishop), heiress to the private lands of the Kamehameha family, to provide for young people of Hawaiian ancestry "first and chiefly a good education in the common English branches, and also instruction in morals and in such useful knowledge as may tend to make good and industrious men and women". The schools opened for boys in 1887, and for girls in 1894 [3].

2 Immigration into the U.S. slowed down significantly between the late 1920 s and the early 1960s, due to the legal restrictions set in the 20s, the subsequent Depression and WW II. This in part explains the gaps between the $3^{\text {rd }}$ and the $4^{\text {th }}$ waves.
}

years of college. For immigrants with college or higher education, the proportions that are employed in professional and managerial jobs are about equal to that of native-born Americans [18].

\section{RESEARCH THESIS}

Bridging the history of Hawaii and the history of immigration to the U.S., it is important to note that Hawaii is very similar to the mainland states in that its current population is primarily composed of immigrants or descendants of immigrants who have arrived in the last 150 years and who have surpassed the indigenous population in size and socioeconomic status. Immigration has significantly changed both the mainland states and Hawaii in the last two hundred years.

The declining Native Hawaiian population in the $19^{\text {th }}$ century prompted the then Hawaii Kingdom to adopt a policy of encouraging immigration of Pacific Islanders from outside Hawaii to refresh its native population. Pacific islanders from outside Hawaii were thus to be accepted as Hawaiians at that time, much the same as Pacific Islander settlers became Hawaiians 1,500 years ago in the first place. Clearly, the racial, ethnic and cultural proximity between Hawaiians and other Pacific islanders was fully acknowledged by the Kingdom of Hawaii and the native Hawaiian people in the $19^{\text {th }}$ century. Those proximities still exist, and the Polynesians who immigrate to Hawaii today will be the only outside source with close racial, ancestral, ethnic and cultural relatedness to Hawaiians. Because of these proximities, in fact, they have had a higher probability to marry Hawaiians than non-Polynesians, and will therefore be part of Hawaiians in future generations [5]. If this trend continues, in which ways does their immigration possibly impact the Hawaiian indigenous population in its size and socioeconomic status?

In this paper, I follow a research thesis of the Hawaiian identity that is characterized by change, inclusiveness and self-identification. My particular focus is on future Hawaiians' racial, ethnic and socioeconomic composition as linked to immigration into Hawaii in the past 30 years. This thesis is similar to the phenomenon of ethnogenesis that has been observed in the mainland U.S. among small racial and ethnic minorities [19].

Hawaiian identity has continued to evolve racially, ethnically, culturally and socio-economically, ever since Hawaii was exposed to the outside world 1500 years ago. The most important mechanism of this demographic change has been intermarriage. As a result, the Hawaiian culture has changed relatively little but the people who preserve it gradually became racially mixed over the years. The identity of a Hawaiian thus takes the form of inclusiveness, self-identification and willingness to be part of a whole. The definition of being a Hawaiian based on blood quantum will eventually fade off, since the number and proportion of individuals with at least $50 \%$ aboriginal Hawaiian blood will inevitably dwindle in face of the large scale of intermarriage in the islands. For future generations, it is less and less an issue how racially pure Hawaiians are, but that they identify themselves as Hawaiians.

This thesis of ethnic identity is unique to Hawaiians, because other peoples in Hawaii all have their sources of racial 
and ethnic origins outside the islands ${ }^{3}$ and their identity won't change the way Hawaiians do. For example, the ethnic Japanese in Hawaii can identify Japan as the source of their racial, cultural and ethnic origin, so do many other groups in the islands.

The only close resemblance of such a source origin for Hawaiians can be found in non-Hawaiian Polynesians, from whom the Hawaiians became. In this regard, it is important to understand the contemporary immigration of Polynesians from the Pacific Islands to Hawaii, and the characteristics they bring with them. This study attempts to provide evidence in support to the research thesis of changing Hawaiian identity, by focusing on two aspects of the Polynesian immigrants: their scale of immigration and their socio-economic status. The U.S. Immigration and Naturalization records from 1971 to 2000 will be utilized in the analysis.

I attempt to answer four questions as related to the research thesis, based on the history of U.S. immigration and the unique racial and ethnic compositions in Hawaii.

Question 1: Does Hawaii receive proportionately the same immigrants as other states of the Union?

Question 2: Are immigrants from Pacific Island nations more likely to settle down in Hawaii than they would in other states?

Question 3: Do immigrants from the Pacific who settle down in Hawaii have the same occupational prestige as those who go to other states?

Questions 4: Have the patterns of Pacific immigration to Hawaii remained stable or have they changed between 1971 and 2000 ?

The first question is based on the fact that the United States of America is one of the most attractive international immigration destinations largely due to its economic pulling forces. It is thus assumed that proportionately more immigrants would settle down in states with a greater variety of jobs than states with lower job opportunities. Hawaii apparently pales in comparison with most mainland states in job availability and variety since Hawaii's industry is almost exclusively linked to tourism and the state does not have a lot of traditional manufacturing or agricultural productions.

The second question assumes that Pacific Islanders from Pacific island nations continue their thousands of years of tradition to migrate across the Pacific among the islands, as did their ancestors who settled in the Hawaiian Islands and became the first Hawaiians. Racial, cultural, historical and climatic proximities make Hawaii a more attractive destination to immigrants from the Pacific than other states in mainland U.S.

The third question follows the first. Since Hawaii does not have as many manual-labor job opportunities as other states that have more diversified industrial and agricultural labor markets, Hawaii is perhaps not as attractive to lowskilled immigrants. Those who settle in Hawaii are thus assumed to have relatively higher occupational prestige than those go elsewhere.

\footnotetext{
3 Hawaiians living on the mainland states originally migrated from the Hawaii islands and they are not sources of Hawaiians.
}

The last question asks for an examination of the longitudinal patterns of immigration and the status of the immigrants. Because the time span examined in this study is within the fourth wave of immigration, it is anticipated that immigration from the Pacific will have a relatively consistent impact over time on the changing Hawaiian identity.

Immigration patterns based on the answers to these questions will help us understand the two central issues related to the research thesis raised in this paper: to what an extent Hawaii's Pacific Islander population is changed by immigration, and how the immigrants affect the future socioeconomic status of Hawaiians and Pacific islanders in Hawaii.

\section{METHODOLOGY}

Data and variables. Data used for analysis in this study are INS (Immigration and Naturalization Service) immigrant data from 1971 to 2000 . The data sets were obtained through Inter-university Consortium for Political and Social Research [20]. Established in 1962, ICPSR is an integral part of the infrastructure of social science research. It maintains and provides access to a vast archive of social science data for research and instruction, and offers training in quantitative methods to facilitate effective data use.

The INS immigrate data contain all immigrants legalized into America by year from 1971 to 2000, either they were new arrivals or had been in the nation as non-immigrants but granted a status change. Variables in the data set include age, sex, occupation, marital status, nation of origin, intended home states, port of entry, visa status upon arrival (only for individuals who obtained permanent residency through status change), labor classification, refugee status, etc.

Besides the INS immigrant data, U.S. census data of the Hawaii state are also used as a backdrop to verify our analysis of the INS data.

Method. The INS immigrant data will be first described in Tables $\mathbf{1}$ to $\mathbf{3}$, to compare immigrants by nation of origin, chosen home states, and selected demographic characteristics. A multi-variate logistic regression analysis then compares the odds of choosing Hawaii as home states (Table 4), followed by a curve regression time-series analysis examines changes over time.

Curve regression is one of the commonly used time series methods when time is the most important independent variable in the analysis. Curve regression calculates the best fit between its model and data using a variety of curve estimates, including linear, cubic and logarithmic models [21]. Results of curve regression are presented in Table 5, Figs. (1) and (2).

Finally, the U.S. Census and Hawaii state data are presented to provide a reference point to the INS data analysis. U.S. Census and Hawaii State demographic data are presented in Tables 6 and 7.

\section{FINDINGS}

Descriptive analysis. Table 1 ranks number of immigrants legalized between 1971 and 2000 by intended home states and nation of origin. Nation of origin is grouped into nations in the Pacific region vs. all nations. For the sake of 
convenience, the INS definition of what nations are from the Pacific region is adopted, as listed at the end of Table $\mathbf{1 .}$

Under the column of all nations, the state of Hawaii received $1.24 \%$ of all immigrants who were legalized between 1971 and 2000, a proportion much larger than its fair share if size of state population is the only consideration (In 2000, Hawaii's population of 1.21 million ranks 41 st among the 50 states, less than $0.5 \%$ of the national total). This finding apparently answers the first research question that Hawaii gets proportionately more immigrants than other states. In fact, Hawaii is almost 2.5 times more likely to be the home state for immigrants, compared to the national average when state population is the only consideration. To put it in perspective, although California has received significantly more Pacific immigrants than Hawaii, its population of 33 million is over 27 times larger than Hawaii's and on a per capita basis Hawaii has actually had more Pacific immigrants.

When nation of origin is limited to the Pacific region, Hawaii has received $8.74 \%$ of all immigrants, ranking \#2 among all states (versus \#16 when immigrants of all nations are included). This is a strong indication that immigrants from the Pacific nations are much more likely to settle down in Hawaii than they would in other states.

Table 1. Intended Home State for Immigrants: 1971 to 2000

\begin{tabular}{|c|c|c|c|c|c|c|}
\hline \multirow[b]{2}{*}{ Rank } & \multicolumn{3}{|c|}{ Immigrants from All Nations } & \multicolumn{3}{|c|}{ Immigrants from Pacific Nations } \\
\hline & Home state & Number & Percent & Home State & Number & Percent \\
\hline 1 & California & $4,528,307$ & $25.90 \%$ & California & 55168 & $42.44 \%$ \\
\hline 2 & New York & $3,152,456$ & $18.03 \%$ & Hawaii & 11356 & $8.74 \%$ \\
\hline 3 & Florida & $1,309,948$ & $7.49 \%$ & New York & 7201 & $5.54 \%$ \\
\hline 4 & Texas & $1,257,838$ & $7.19 \%$ & Washington & 4493 & $3.46 \%$ \\
\hline 5 & New Jersey & 990,070 & $5.66 \%$ & Texas & 4372 & $3.36 \%$ \\
\hline 6 & Illinois & 883,589 & $5.05 \%$ & Utah & 3861 & $2.97 \%$ \\
\hline 7 & Massachusetts & 475,960 & $2.72 \%$ & Florida & 3258 & $2.51 \%$ \\
\hline 8 & Pennsylvania & 350,685 & $2.01 \%$ & Illinois & 2658 & $2.04 \%$ \\
\hline 9 & Virginia & 340,823 & $1.95 \%$ & Oregon & 2608 & $2.01 \%$ \\
\hline 10 & Michigan & 321,601 & $1.84 \%$ & New Jersey & 2480 & $1.91 \%$ \\
\hline 11 & Washington & 314,726 & $1.80 \%$ & Massachusetts & 2297 & $1.77 \%$ \\
\hline 12 & Maryland & 276,682 & $1.58 \%$ & Pennsylvania & 2085 & $1.60 \%$ \\
\hline 13 & Connecticut & 233,390 & $1.33 \%$ & Colorado & 2057 & $1.58 \%$ \\
\hline 14 & Ohio & 217,787 & $1.25 \%$ & Michigan & 1859 & $1.43 \%$ \\
\hline 15 & Hawaii & 216,440 & $1.24 \%$ & Virginia & 1727 & $1.33 \%$ \\
\hline 16 & Georgia & 187,013 & $1.07 \%$ & Ohio & 1687 & $1.30 \%$ \\
\hline 17 & Arizona & 184,003 & $1.05 \%$ & Guam & 1672 & $1.29 \%$ \\
\hline 18 & Minnesota & 158,018 & $0.90 \%$ & Arizona & 1587 & $1.22 \%$ \\
\hline 19 & Puerto Rico & 155,480 & $0.89 \%$ & Georgia & 1303 & $1.00 \%$ \\
\hline 20 & Colorado & 143,703 & $0.82 \%$ & Connecticut & 1292 & $0.99 \%$ \\
\hline 21 & Oregon & 129,938 & $0.74 \%$ & Minnesota & 1172 & $0.90 \%$ \\
\hline 22 & North Carolina & 115,668 & $0.66 \%$ & Nevada & 1048 & $0.81 \%$ \\
\hline 23 & Wisconsin & 98,737 & $0.56 \%$ & Missouri & 1027 & $0.79 \%$ \\
\hline 24 & Missouri & 97,850 & $0.56 \%$ & Maryland & 1002 & $0.77 \%$ \\
\hline 25 & Louisiana & 96,752 & $0.55 \%$ & North Carolina & 818 & $0.63 \%$ \\
\hline 26 & Nevada & 93,105 & $0.53 \%$ & Wisconsin & 807 & $0.62 \%$ \\
\hline 27 & Indiana & 85,684 & $0.49 \%$ & Indiana & 742 & $0.57 \%$ \\
\hline
\end{tabular}


Table 1. contd....

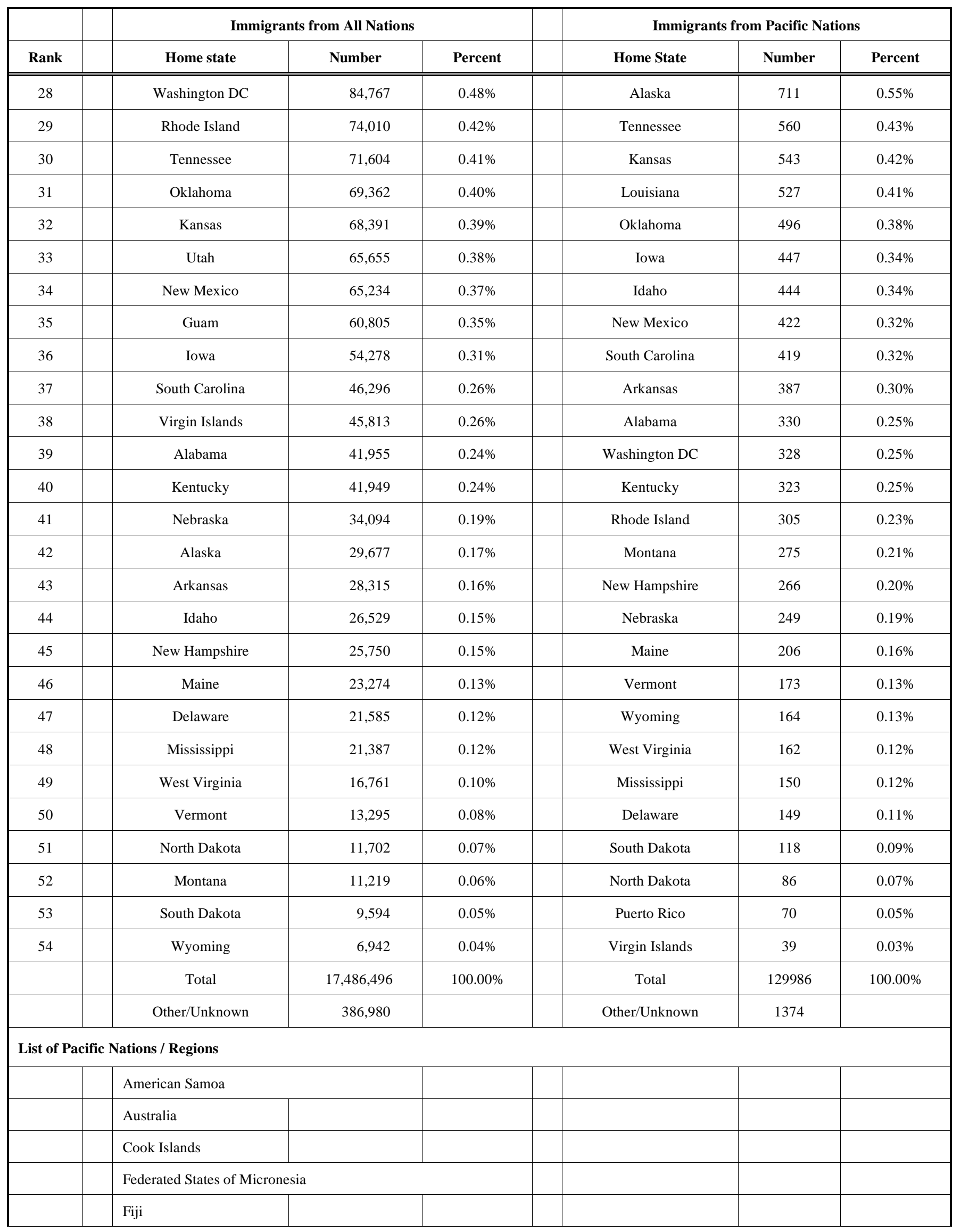


Table 1. contd....

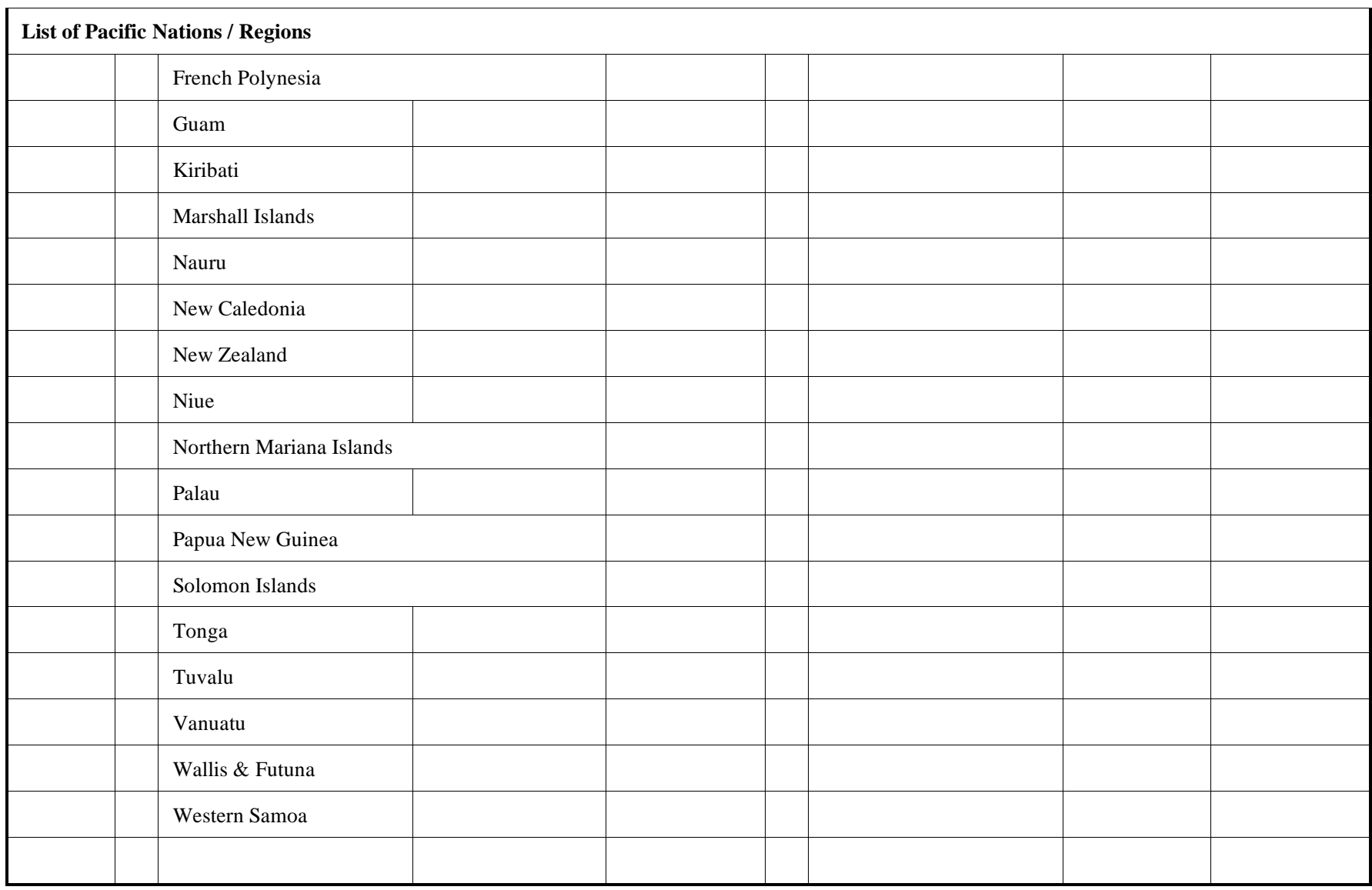

Table 2. Comparison Among Pacific Nation Immigrants for Intended Home State

\begin{tabular}{|c|c|c|c|c|c|c|c|}
\hline \multirow{3}{*}{ Pacific Nations } & \multirow{3}{*}{$\begin{array}{c}\text { Total \# of } \\
\text { Immigrants by } \\
\text { Nation }\end{array}$} & \multicolumn{4}{|c|}{ Intended Home State } & \multirow{3}{*}{$\begin{array}{c}\begin{array}{c}\text { Odds to } \\
\text { Choose Hawaii }\end{array} \\
\begin{array}{c}\text { Against all } \\
\text { Pacific Nations }\end{array}\end{array}$} & \multirow{3}{*}{$\begin{array}{c}\text { Against all } \\
\text { Nations }\end{array}$} \\
\hline & & \multicolumn{2}{|c|}{ Other States } & \multicolumn{2}{|c|}{ Hawaii } & & \\
\hline & & $\#$ & $\%$ & $\#$ & $\%$ & & \\
\hline American Samoa & 1791 & 760 & $42.43 \%$ & 1031 & $57.57 \%$ & 6.59 & 46.42 \\
\hline Tuvalu & 19 & 10 & $52.63 \%$ & 9 & $47.37 \%$ & 5.42 & 38.20 \\
\hline Cook Islands & 47 & 28 & $59.57 \%$ & 19 & $40.43 \%$ & 4.63 & 32.60 \\
\hline Nauru & 16 & 11 & $68.75 \%$ & 5 & $31.25 \%$ & 3.58 & 25.20 \\
\hline French Polynesia & 1027 & 727 & $70.79 \%$ & 300 & $29.21 \%$ & 3.34 & 23.56 \\
\hline Niue & 12 & 10 & $83.33 \%$ & 2 & $16.67 \%$ & 1.91 & 13.44 \\
\hline $\begin{array}{l}\text { Marshall Is- } \\
\text { lands* }\end{array}$ & 3420 & 2958 & $86.49 \%$ & 462 & $13.51 \%$ & 1.55 & 10.89 \\
\hline Solomon Islands & 150 & 136 & $90.67 \%$ & 14 & $9.33 \%$ & 1.07 & 7.53 \\
\hline Vanuatu & 49 & 45 & $91.84 \%$ & 4 & $8.16 \%$ & 0.93 & 6.58 \\
\hline
\end{tabular}


Table 2. contd....

\begin{tabular}{|c|c|c|c|c|c|c|c|}
\hline \multirow{3}{*}{ Pacific Nations } & \multirow{3}{*}{$\begin{array}{c}\text { Total \# of } \\
\text { Immigrants by } \\
\text { Nation }\end{array}$} & \multicolumn{4}{|c|}{ Intended Home State } & \multirow{3}{*}{$\begin{array}{c}\text { Odds to } \\
\text { Choose Hawaii } \\
\text { Against all } \\
\text { Pacific Nations }\end{array}$} & \multirow{3}{*}{$\begin{array}{c}\text { Against all } \\
\text { Nations }\end{array}$} \\
\hline & & \multicolumn{2}{|c|}{ Other States } & \multicolumn{2}{|c|}{ Hawaii } & & \\
\hline & & \# & $\%$ & \# & $\%$ & & \\
\hline New Zealand & 19737 & 18376 & $93.10 \%$ & 1361 & $6.90 \%$ & 0.79 & 5.56 \\
\hline $\begin{array}{c}\text { Papua New } \\
\text { Guinea }\end{array}$ & 462 & 432 & $93.51 \%$ & 30 & $6.49 \%$ & 0.74 & 5.24 \\
\hline New Caledonia & 161 & 154 & $95.65 \%$ & 7 & $4.35 \%$ & 0.50 & 3.51 \\
\hline Australia & 56912 & 55368 & $97.29 \%$ & 1544 & $2.71 \%$ & 0.31 & 2.19 \\
\hline Fiji & 28192 & 27690 & $98.22 \%$ & 502 & $1.78 \%$ & 0.20 & 1.44 \\
\hline Guam & 67 & 67 & $100.00 \%$ & 0 & $0.00 \%$ & - & - \\
\hline Wallis \& Futuna & 19 & 19 & $100.00 \%$ & 0 & $0.00 \%$ & - & - \\
\hline Total & 129986 & 118630 & $91.26 \%$ & 11356 & $8.74 \%$ & 1.00 & 7.05 \\
\hline
\end{tabular}

* Marshall Islands are combined with Palau, Northern Mariana islands and Federates States of Micronesia in the INS data.

Table 2 looks inside the Pacific region and ranks the probability of choosing Hawaii as home state by nation. Samoa (American and Western) leads the nations in the likelihood of its immigrants choosing Hawaii (INS lists American Samoa as an independent originating nation). American and Western Samoan immigrants are respectively 6.59 times and 5.43 times more likely to choose Hawaii as home state than the average immigrant from this region. The odds increased to over 46 and 38 times when Samoas are compared to all immigrants regardless of nation of origin. It should be noted that the INS data do not have indicators of race, and nation of origin is used in this study as a rough measure of the immigrants' racial or ethnic background because it can be reasonably assumed that the majority of the immigrants from the Pacific island nations are Pacific Islanders. This assumption, however, is in serious jeopardy when Australia and New Zealand are included in the Pacific region (Table 1), since ethnic Pacific Islanders are a minority in these two nations. The inclusion of these two large nations (ranked \#1 and \#3 in number of immigrants provided to the U.S. from the region), however, may in fact reflect the inclination of Pacific Islander immigrants to live in Hawaii, because their immigrants have lower probability to settle down in Hawaii than the average immigrant from the Pacific region. Fiji, on the other hand, is an exception to what might be expected: the probability of Fijian immigrants choosing to live in $\mathrm{Ha}-$ waii is much lower than the average for the region, albeit higher than that for all immigrants regardless of nation of origin.

The pattern of choosing a home state by nation of origin answers the second research question: Immigrants from $\mathrm{Pa}-$ cific island nations do have an inclination to live in Hawaii once they migrate to the U.S.

Table 3 lists selected demographic characteristics of immigrants by nation of origin and chosen home states. Each of the demographic variables will be briefly discussed.
Sex. While Pacific immigrants tend to be equally male or female whether they chose to live in Hawaii or elsewhere, those from non-Pacific nations are more likely female if they choose Hawaii as home state.

Age. There is little difference in age among immigrants regardless where they came from and where they chose to live.

Legal Status. Legal status in the INS file indicates if the immigrant was a new arrival (landing in the U.S. as an immigrant) or someone who came to the U.S. as a nonimmigrant but adjusted his or her status as an immigrant in that given year. Pacific immigrants are less likely new arrivals if they live in Hawaii, but non-Pacific immigrants are lot more likely to be new arriving immigrants if they chose to live in Hawaii.

Marital Status. Pacific immigrants are more likely to be married at the time of becoming legal immigrants than those from other nations. However, immigrants who live in Hawaii are slightly less likely married.

Profession. This variable examines socio-economic status of the immigrants. Professional and managerial jobs are usually associated with higher prestige than other jobs, and this difference has been well documented across nations and over time [10,22].

Apparently, immigrants who chose Hawaii as home state are less likely to have a professional or managerial job. This is even more pronounced among Pacific immigrants than among those from non-Pacific nations. To be exact, Pacific immigrants with professional jobs are twice as likely to live in other states as living in Hawaii (14.15\% vs. 6.36\%), while the ratio for managerial job holders are almost three times (6.30\% vs. $2.91 \%)$. Pacific immigrants who came to Hawaii are more likely housewives or young students. Those from non-Pacific nations also tend to be more proportionately housewives, but not students. 
Table 3. Selected Characteristics of Immigrants by Nation of Origin and U.S. Home States

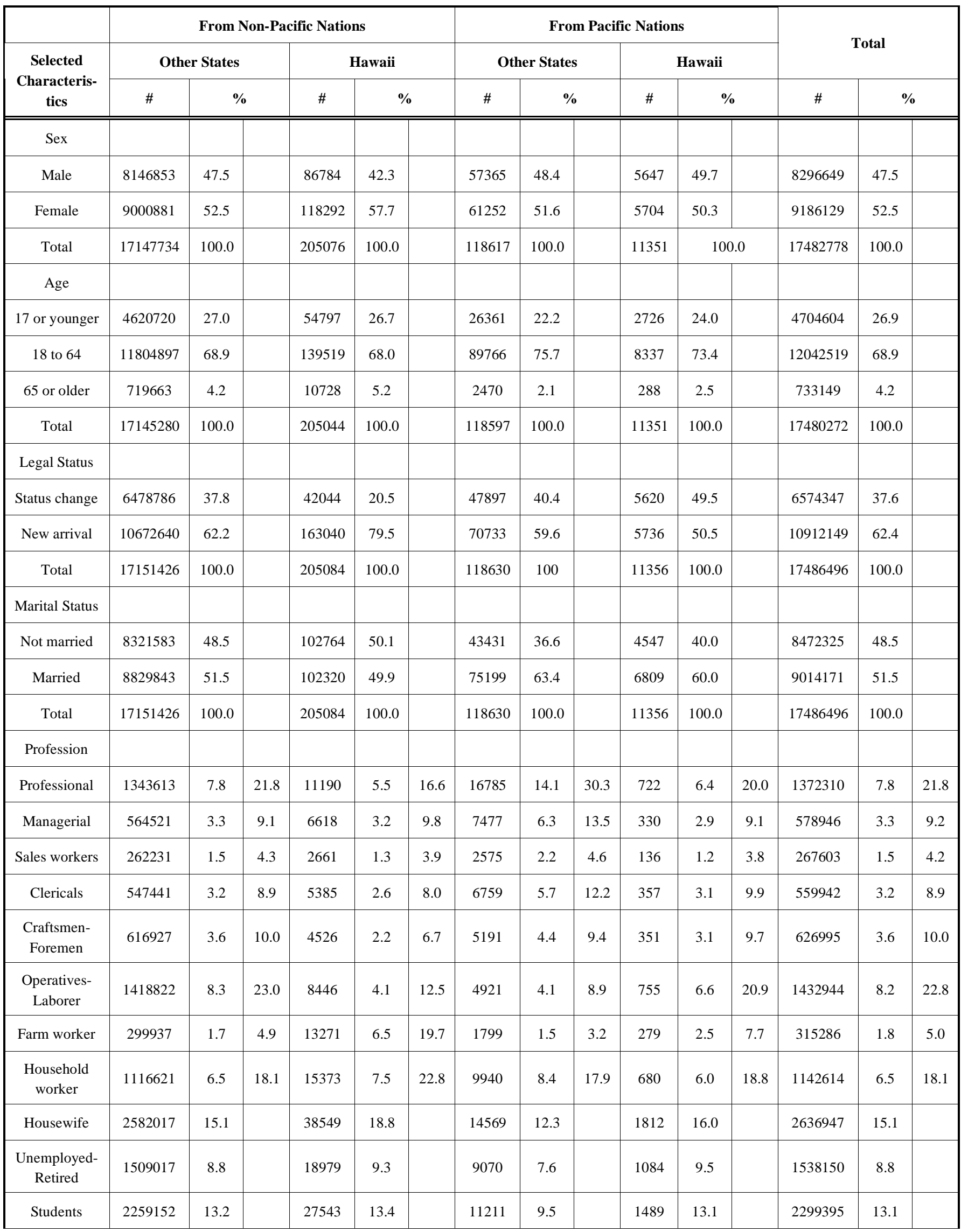


Table 3. contd....

\begin{tabular}{|c|c|c|c|c|c|c|c|c|c|c|}
\hline \multirow{2}{*}{$\begin{array}{c}\text { Selected } \\
\text { Characteris- } \\
\text { tics }\end{array}$} & \multicolumn{4}{|c|}{ From Non-Pacific Nations } & \multicolumn{4}{|c|}{ From Pacific Nations } & \multirow{2}{*}{\multicolumn{2}{|c|}{ Total }} \\
\hline & \multicolumn{2}{|c|}{ Other States } & \multicolumn{2}{|c|}{ Hawaii } & \multicolumn{2}{|c|}{ Other states } & \multicolumn{2}{|c|}{ Hawaii } & & \\
\hline Under 14 & 3274332 & 19.1 & 38493 & 18.8 & 19436 & 16.4 & 1936 & 17.0 & 3334197 & 19.1 \\
\hline Total & 17151426 & 100.0 & 205084 & 100.0 & 118630 & 100.0 & 11356 & 100.0 & 17486496 & 100.0 \\
\hline
\end{tabular}

Note: The second column percentages for profession are calculated only for immigrants who were employed.

Table 4. Logistic Regression Coefficients Showing Effects of Selected Characteristics of Immigrants on Choosing Hawaii as Home State

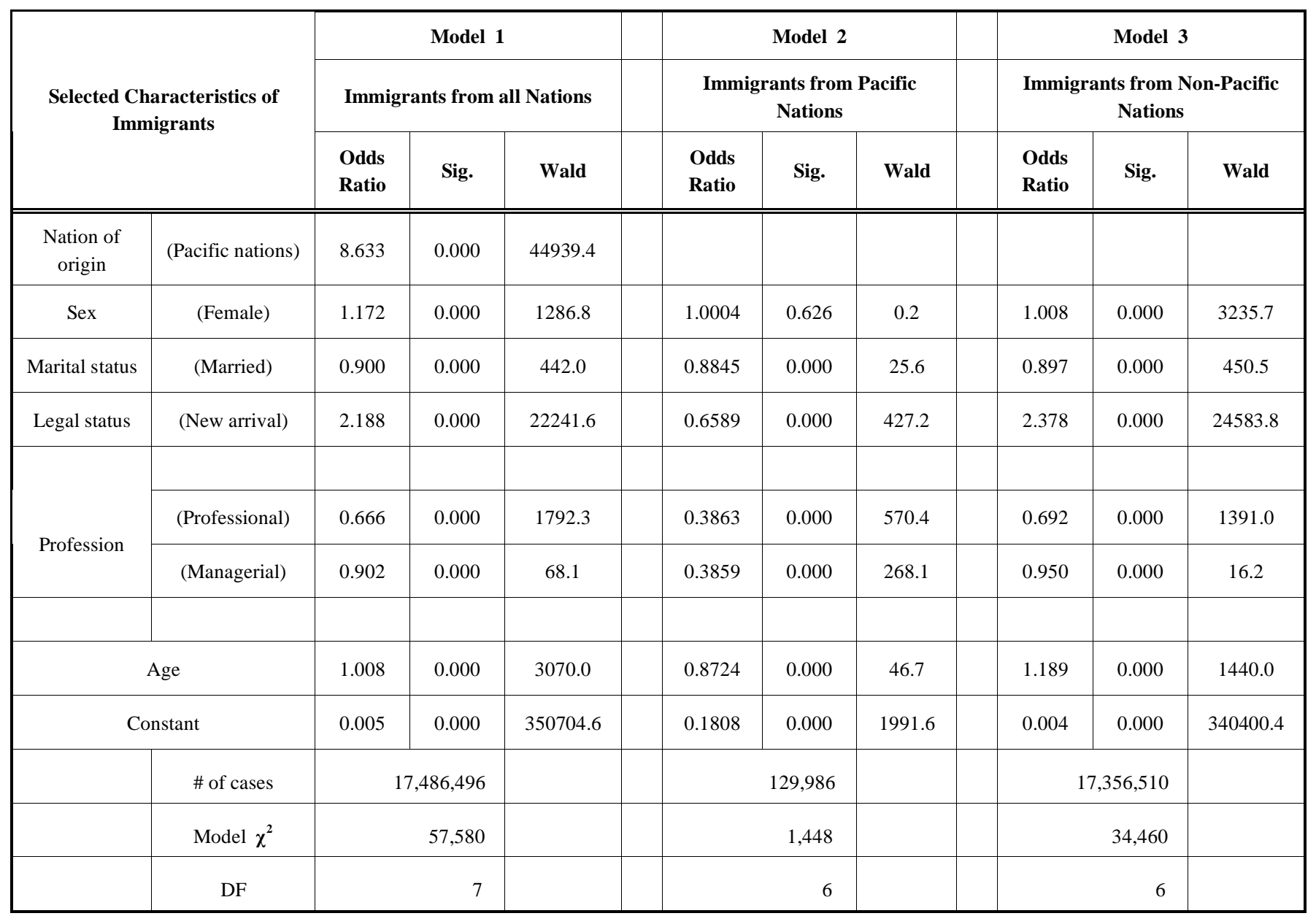

Note: Except fro AGE, all independent variables are categorical. Their default comparison group is Male for SEX, non-Pacific nations for Nation of Origin, Other jobs for Profession, Not married for Marital Status, and Status change for Legal Status

To make the above comparison more accurate, the percentages of profession are re-calculated to include only those who have jobs (the last five categories are excluded), as presented on the second percent column in Table 3. The pattern that fewer professional and managerial jobholders chose to live in Hawaii, especially if they came from the Pacific, remains unchanged.

$\mathrm{t}$ is evident that the answer to the third research question is not as expected. Regardless where the immigrants came from, those with professional and managerial jobs were less likely to settle down in Hawaii. Those who did were more likely farm workers, when compared to immigrants who landed in other states after their immigration.

Logistic regression analysis. Table 4 shows in three logistic models the effects of the variables in Table $\mathbf{3}$ on probabilities of choosing Hawaii as home state. The dependent variable in all three models is whether an immigrant chose to live in Hawaii or elsewhere, with choosing not to live in 
Hawaii as the default comparison. The coefficients thus show the effects of the independent variables on choosing to live in Hawaii. The three models differ in their inclusion of cases. The first model has all immigrants, the second only has immigrants from Pacific nations, and the third only has immigrants from non-Pacific nations.

Except Age, all the independent variables are treated as categories, with two of them combining some of their original values to make comparison simpler: Marital status is coded with only two categories: married and not married (combining single, widowed and divorced), and Profession is coded with three categories: Professional, Managerial and Other (combining all the other job categories). The default comparison of these categorical variables is the one not shown in the table (Male for Sex, Other for Professional, Not married for Marital status, Status change for Legal status, and Non-Pacific nations for Nation of origin).

To make the reading of the coefficients more direct, odds ratios instead of $\log$ odds are reported in Table 4, with their significance and Wald statistics. It should be noted that the statistical significance in these models might not mean much, since the INS data are extremely large and they are not a sample (but the population itself). The significance reported in Table $\mathbf{4}$ is at best a reference of relative strength of the independent variables. In this study, I take odds ratio difference of $10 \%(0.10)$ or larger as having any real-world difference. Although this is an arbitrary criterion, it nevertheless provides a standard comparison to the size of the regression coefficients. Logistic regression coefficients that are smaller than $10 \%$ will be dismissed from discussion as not meaningful even if they are statistically significant.

In Model 1 all independent variables have a meaningful impact on the probability of choosing to live in Hawaii except age (smaller than 10\%). Immigrants who chose to live Hawaii are $17 \%$ more likely to be women than to be men, over twice as likely to be new arrivals, but they are $10 \%$ less likely to be married. Most important to our analysis, immigrants who went to live in Hawaii tend to hold lower-status jobs. They are $90 \%$ as likely to have a managerial job, and only $66.6 \%$ as likely to be a professional, when compared to those who didn't choose to live in Hawaii. Finally, after controlling for all these variables, Pacific immigrants are 8.6 times more likely to choose Hawaii as home state than immigrants from non-Pacific nations.

The effects of the demographic characteristics examined in Model 2 and 3 change quite a bit from those in Model 1. Pacific immigrants who went to live in Hawaii are younger and less likely to be new arrivals than those who didn't, just the opposite of the immigrants who came from non-Pacific nations. They are similar, however, in that they are less likely married, and equally likely to be men or women.

However, when examining the most important independent variable in our study, profession, a consistent pattern is found across the three models: those who chose to live in Hawaii have lower occupational prestige, especially the immigrants from Pacific nations. Pacific immigrants with a professional or managerial job are only $39 \%$ as likely to choose Hawaii as home state, other things being equal. For immigrants from non-Pacific nations, there is no meaningful difference among managerial jobholders in whether they would live in Hawaii, but those who have professional jobs are about $30 \%$ less likely to live in Hawaii as they would elsewhere.

The results of the logistic models confirmed our earlier findings and answered our third question. Immigrants who settle down in Hawaii have lower job status by quite a margin, after controlling for other demographic variables in the INS data.

Time series analysis. The INS data cover a span of 30 years from 1971 to 2000 . While the absolute number of immigrants has been increasing in these 30 years [14], the demographic patterns that were examined above may or may not have remained consistent. A curve regression model was used to examine if there has been any change, and its results are presented in Table 5, Figs. (1) and (2).

The only independent variable used in the curve estimates is time (30 years), while the dependent variables are average annual percent of immigrants who chose to live in Hawaii and of the demographic characteristics listed in Table 3 . For these demographic variables, only one category is chosen. For example, the average annual percentage of immigrants age 18 to 64 is chosen in the curve estimate for age, and married percent of the immigrants is chosen for marital status.

After testing various coefficient estimates, I finally chose the linear model because other curves do not add to the explanation of the dependent variables. Also to be noted is that the statistical significance of the curve estimates given in Table 6 is a meaningful indicator of the effect of time, because the sample size is only 30 (1971 to 2000 with one data point per year).

Part A of Table 5 shows curve regression estimates in a model that includes all immigrants regardless of their nation of origin. The first three variables are unique to Part A and they illustrate the overall trends of immigration to the United States during the 30 years. On average, number of immigrants legalized in the nation increased 15,657 per year from 1971 to 2000 , at an annual rate of $8.12 \%$. By 2000, the number of immigrants admitted is roughly 3.6 times its size in 1971. With this rising trend, however, the proportion of Pacific immigrants declined slightly, at $100^{\text {th }}$ of a percent annually and $0.3 \%$ in total (Also see Fig. 1).

The other variables in Part A are the same as in Part B and $\mathrm{C}$, and they all changed over the years except sex and marital status. Percentages of immigrants who chose Hawaii as home state, who were new arrivals, and who held professional or managerial jobs declined over the years, while percentage of working age immigrants (18 to 64) has increased in these years.

Part B has only immigrants from Pacific nations. Over the 30 years, proportions of these immigrants who chose to live in Hawaii, who were female, and who were new arrivals have decreased, while those of working age and those who were married have increased. Percent of Pacific immigrants with professional and managerial jobs has largely remained unchanged. 
Table 5. Curve Regression Analysis of Immigration to Hawaii: 1971 to 2000

\begin{tabular}{|c|c|c|c|c|c|}
\hline$\underline{\text { Dependent Variable }}$ & Coefficient & R Square & D.F. & $\mathbf{F}$ & Sig. \\
\hline \# of immigrants admitted & 15657.10 & 0.74 & 28 & 78.78 & 0.000 \\
\hline$\%$ of immigrants admitted & $8.12 \%$ & 0.74 & 28 & 78.78 & 0.000 \\
\hline$\%$ choosing Hawaii as home state & $-0.04 \%$ & 0.92 & 28 & 300.27 & 0.000 \\
\hline$\%$ female & $0.06 \%$ & 0.08 & 28 & 2.48 & 0.127 \\
\hline$\%$ professional or managerial jobs & $-0.13 \%$ & 0.54 & 28 & 33.22 & 0.000 \\
\hline$\%$ married & $-0.06 \%$ & 0.07 & 28 & 2.07 & 0.162 \\
\hline \multicolumn{6}{|c|}{ B. Immigrants From Pacific Nations } \\
\hline$\%$ choosing Hawaii as home state & $-0.37 \%$ & 0.74 & 28 & 80.59 & 0.000 \\
\hline$\%$ female & $-0.13 \%$ & 0.49 & 28 & 26.52 & 0.000 \\
\hline$\%$ professional or managerial jobs & $0.07 \%$ & 0.05 & 28 & 1.44 & 0.241 \\
\hline \multicolumn{6}{|c|}{ C. Immigrants From Non-Pacific Nations } \\
\hline$\%$ choosing Hawaii as home state & $-0.04 \%$ & 0.90 & 28 & 263.80 & 0.000 \\
\hline$\%$ female & $0.06 \%$ & 0.08 & 28 & 2.55 & 0.122 \\
\hline$\%$ professional or managerial jobs & $-0.13 \%$ & 0.55 & 28 & 33.91 & 0.000 \\
\hline$\%$ new arrivals & $-0.94 \%$ & 0.68 & 28 & 59.79 & 0.000 \\
\hline$\%$ age $18-64$ & $0.13 \%$ & 0.31 & 28 & 12.73 & 0.001 \\
\hline$\%$ married & $-0.06 \%$ & 0.07 & 28 & 2.17 & 0.152 \\
\hline
\end{tabular}

Note: The independent is TIME (1971 to 2000) in all models.

Part C shows curve estimates that include only nonPacific immigrants, and the results are by and large the same as in Part A, because the overwhelming majority of the total immigrants came from non-Pacific nations and their averages set trends for all immigrants.

The findings of the curve regression estimates are also illustrated in Figs. (1) and (2). Fig. (1) has four trends from
1971 to 2000 for all immigrants admitted to the U.S. Chart A and $\mathrm{B}$ show the first trend: number and percent of immigrants by year. Chart $\mathrm{C}$ has displays trends: percent of immigrants who came from the Pacific nations and percent of immigrants who chose to live in Hawaii. Chart D describes the fourth trend with percent of immigrants who held professional and managerial jobs. 
A

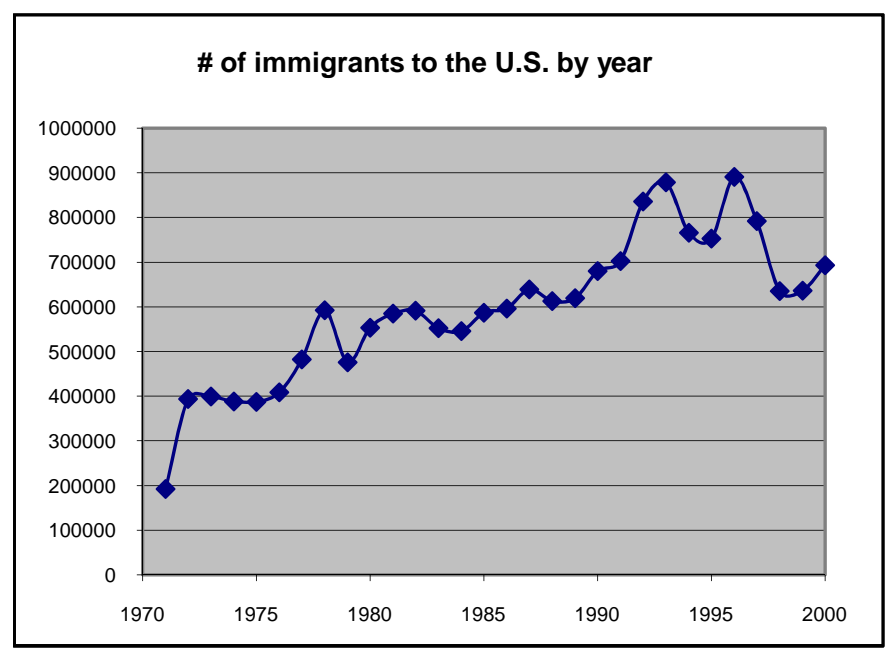

C

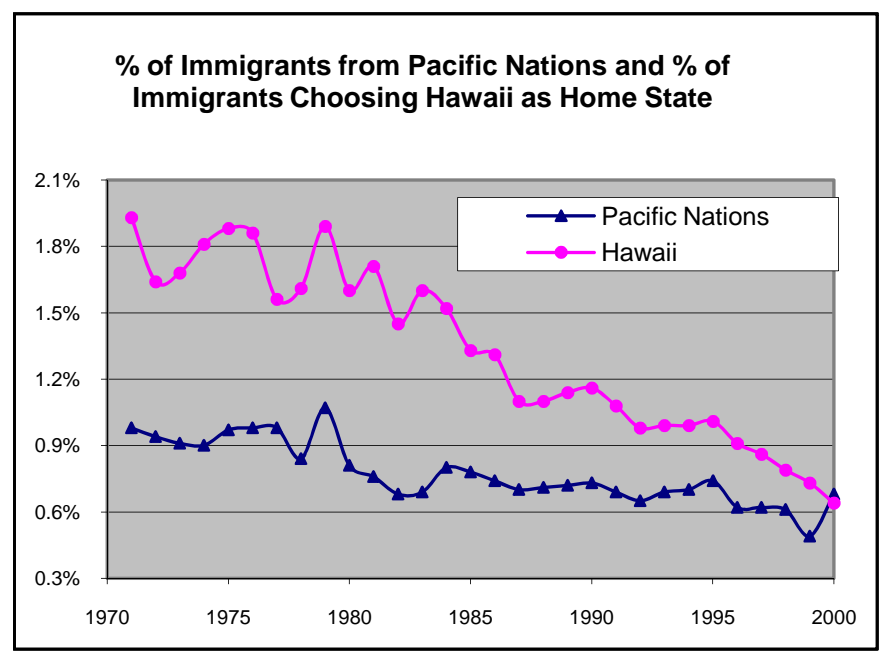

B

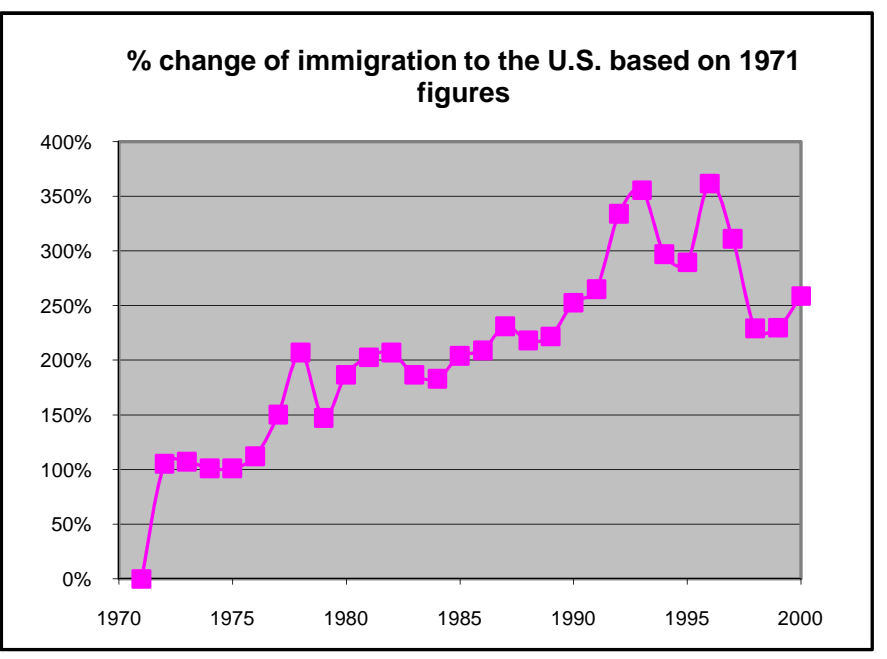

D

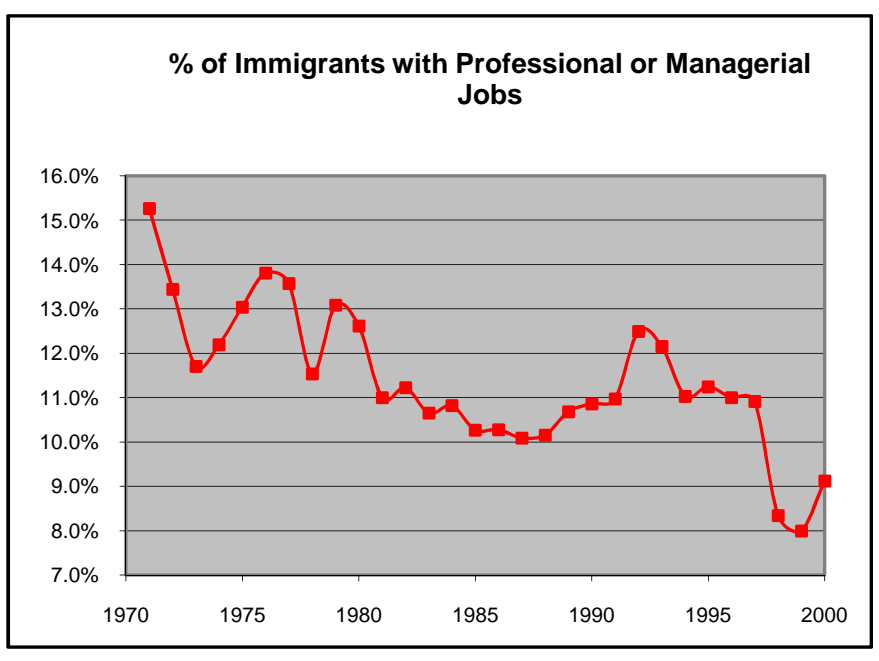

Fig. (1). Time series analysis of immigration to the U.S. from 1971 to 2000 immigrants from all nations.

Chart A and B clearly indicate the overall rising trend of immigration to the U.S. as shown by the curve regression in Table 5. Chart C, on the other hand, shows that from 1971 to 2000 the percentage of all immigrants who came from the Pacific slightly declined from about $1 \%$ to $0.7 \%$, while that of choosing to live in Hawaii declined from about $2 \%$ to $0.6 \%$. The percentage of all immigrants with professional or managerial jobs (regardless of their chosen home state) sharply decreased from over $15 \%$ in 1971 to about $9 \%$ in 2000, as shown in Chart D.

Fig. (2) shows changing trends of choosing Hawaii as home state and holding professional or managerial jobs for Pacific immigrants compared to non-Pacific immigrants. As illustrated in Chart A and B, the proportion of Pacific immigrants who chose to live in Hawaii increased from 1971 to 1976, and then declined all the way to 2000 . On the other hand, the proportion of these immigrants who have professional or managerial jobs, albeit low, remain largely unchanged over the 30 years: it kept consistent from 1971 to 1990, climbed for the next few years and then slightly declined (Curve estimate is not statistically significant in Table 5).

Chart $\mathrm{C}$ and $\mathrm{D}$ describe the same trends as Chart $\mathrm{A}$ and $\mathrm{B}$, but for non-Pacific immigrants. Both percentages of choosing Hawaii as home state and of holding professional and managerial jobs declined during the 30 years from 1971 to 2000 .

In conclusion, the time series analysis indicates that proportions of immigrants who came from the Pacific, who went to live in Hawaii, and who have high-status jobs have gradually declined, upon the background of an overall rise in immigration during the same time period. The only excep- 


\section{Immigrants From Pacific Nations}

A

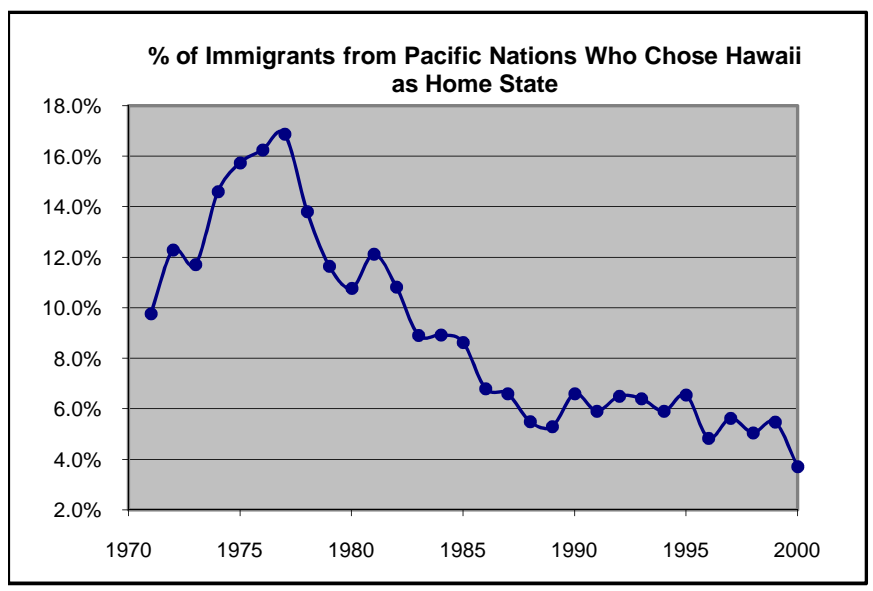

B

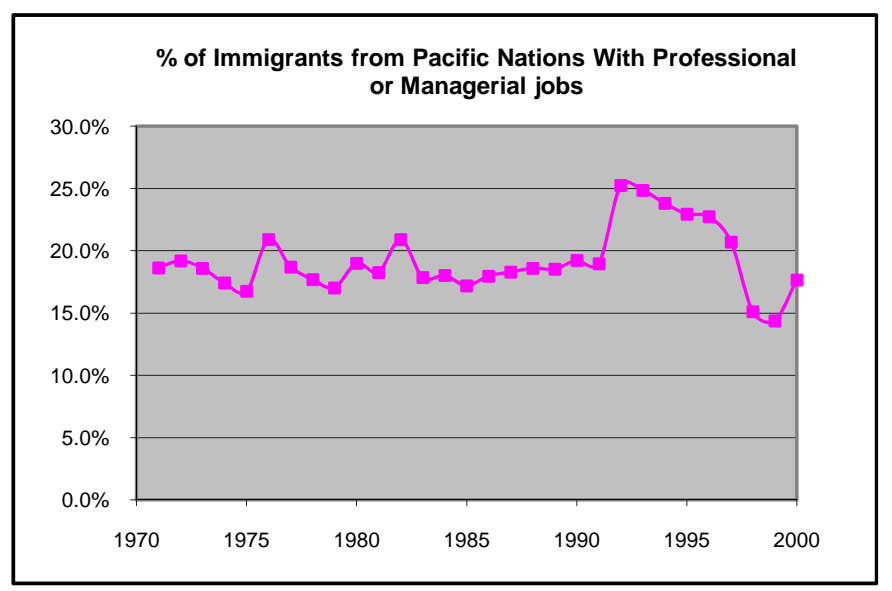

Immigrants From Non-Pacific Nations

C

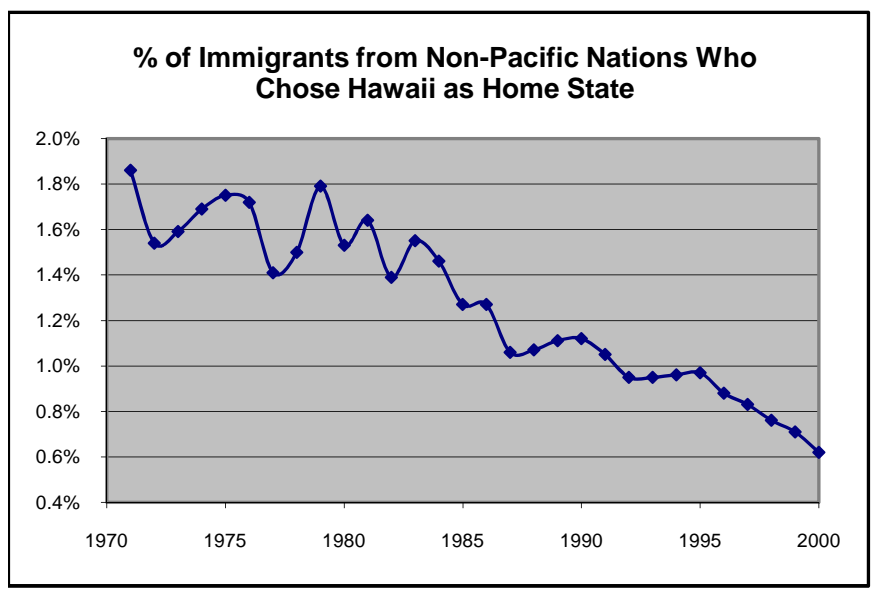

D

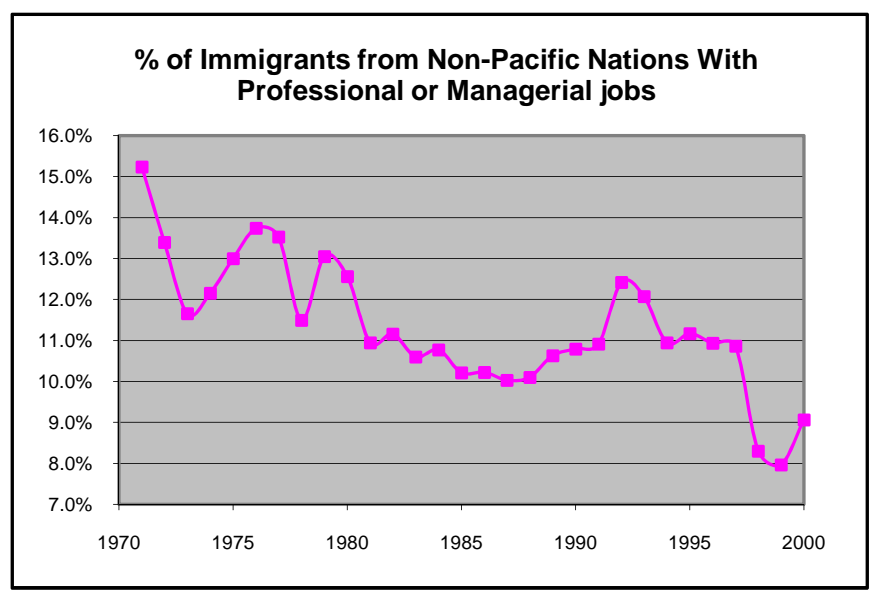

Fig. (2). Time series analysis of immigration to hawaii from 1971 to 2000 pacific nations vs. non-pacific nations.

tion is the percentage of Pacific immigrants who have professional or managerial jobs (regardless of their chosen home state). These findings provide answers to the fourth research question that over time the trends and patterns of immigration have changed, but they also indicate that the answer to the first question might be more complicated when the data are examined longitudinally. In other words, although Hawaii receives more immigrants than the average state when state population is considered (the answer to the first questions when data are analyzed cross-sectionally), over time its share in the national total has been declining.

U.S. Census and Hawaii state data. Intention to live in Hawaii as reported to the INS at the time of obtaining green cards may not be permanent, since people can move freely across states. It is important to verify, even in a very general fashion, the accuracy of the INS data, in terms of how many Hawaii residents were born outside the United States and what jobs they have.

Tables 6 and 7 list demographic and occupational patterns in the state of Hawaii, provided by the U.S. Census and Hawaii state. In 2000 (Table 6), there were a total of 242,590 foreign born Hawaii residents, and the number of international arrivals to Hawaii from 1991 to 2000 totaled 51,629. Generally speaking, these numbers echo the INS figures. As shown in Table 2, a total of 216,440 immigrants chose to live in Hawaii from 1971 to 2000, and the number of new international arrivals reported by the Hawaii state from 1991 to 2000 is roughly $24 \%$ of this total figure. Considering the declining proportions of immigration to Hawaii from the 70 's to 2000, it could be concluded that the INS data and the 
Table 6. A Glimpse of Hawaii's Population: Changes by Source

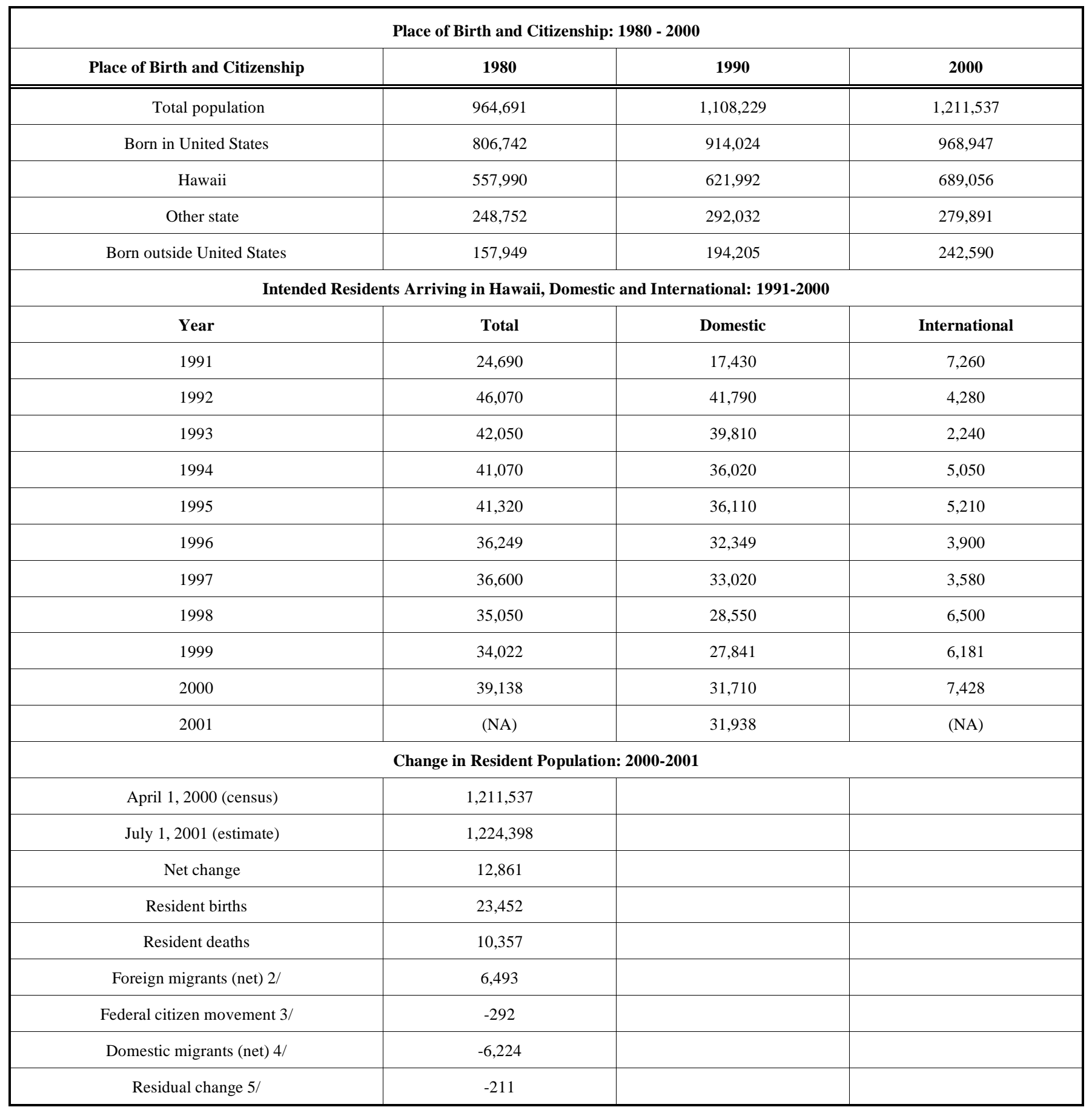

Source: U.S. Bureau of the Census, 1990 Selected Place of Birth and Migration Statistics for States, CPH-L-121, tables 2 and 3; 1990 Age, Nativity, and Citizenship for the United States, States and Counties, CPH-L-114, table 1; data from STF3A, extracted by the Hawaii State Department of Business, Economic Development \& Tourism, Hawaii State Data Center; and U.S. Census Bureau, Census 2000 Table DP-1 "Profile of General Demographic Characteristics: 2000" and Table DP-2 "Profile of Selected Social Characteristics: 2000" (May 2002) <http://censtats.census.gov/data/HI/04015.pdf> accessed June 20, 2002. <http://eire.census.gov/popest/data/counties.php?PHPSESSID=8902fed4e9d188635fcc2f1b680219ab> accessed June 13, 2002. The State of Hawaii Data Book: Table 1.37, 1.52, 1.52, 1.53, 2002.

Census/Hawaii state data are not drastically at odds with each other, especially considering the possibility that immigrants may move after they arrive.

It is to be noted that domestic migration (from mainland states to Hawaii) was negative during 2000 to 2001 in Hawaii, with a net loss of 6,224 , a pattern that has persisted since the early 1990s, probably due to economic hardship the state has experienced. International arrivals, on the other hand, have been on the rise during the same period (with a net gain of 6,493 between 2000 and 2001). Although these numbers are small, they indicate the unique characteristics of Hawaii that foreign immigrants play a role in forming $\mathrm{Ha}-$ 
Table 7. Occupational Categories of Employed Civilians in Hawaii

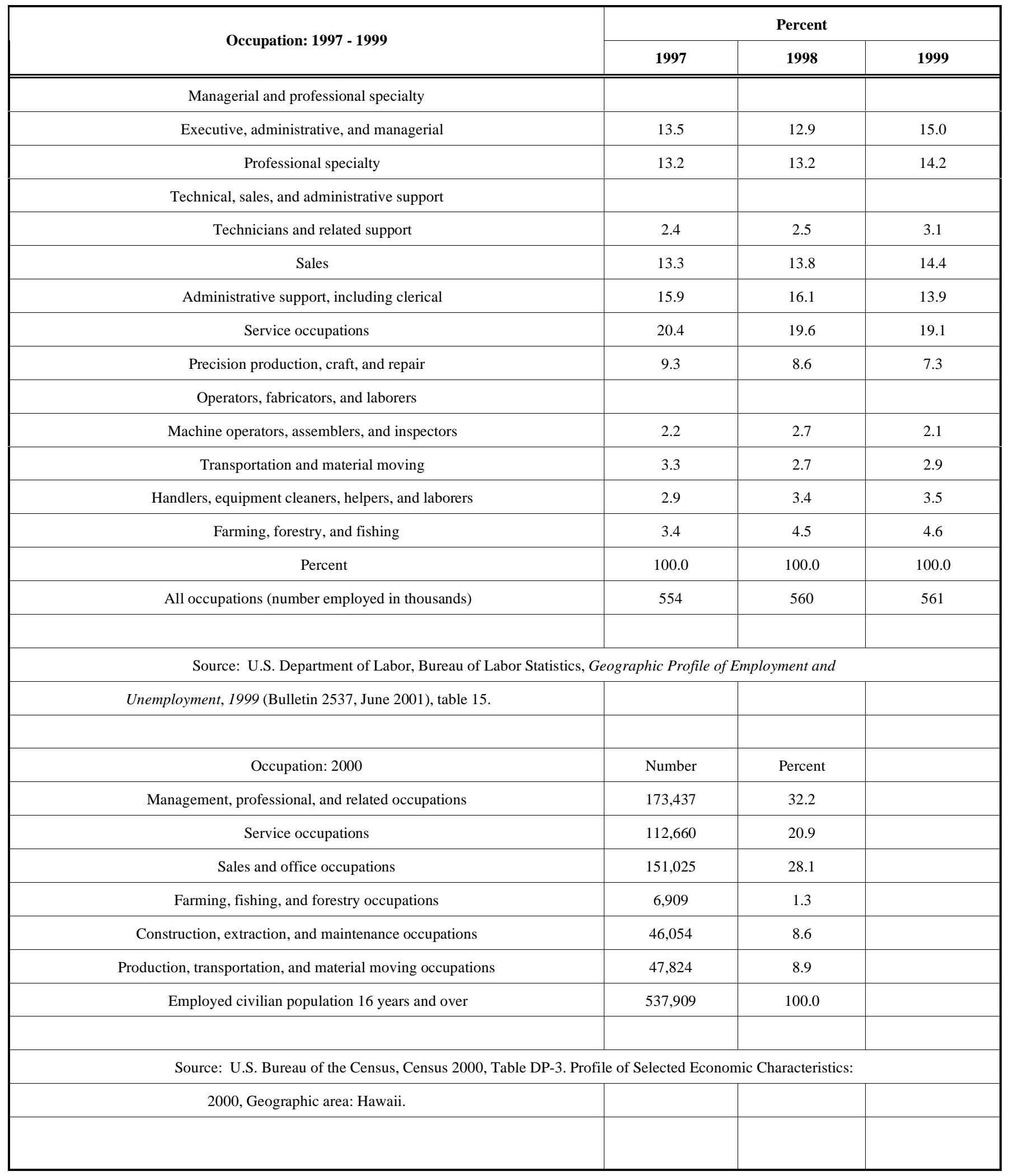

waii's ethnic profiles in the future. In other words, the Pacific Islander immigrants are highly likely to become part of Hawaiians in the future generations in the process of Hawaiians' changing identity.
Table 7 looks at proportions of occupational categories in the state of Hawaii, given by the U.S. Department of Labor and the U.S. Census. These figures suggest that roughly 30 percent of all Hawaii residents who work can be classified as 
having a professional or managerial job. The percentages of professional and managerial jobs given in Table $\mathbf{3}$ from the INS data were $26.4 \%$ (the second occupation percent list). Since the two data sources do not represent the same people (Table $\mathbf{7}$ for the entire state workforce and Table $\mathbf{3}$ for immigrants only), the INS data are only used as a reference of labor supplies from immigration. The slightly lower percentages among the immigrants support the findings that proportionately fewer high-status jobholders came to live in Hawaii.

\section{CONCLUSION AND DISCUSSION}

In this study I examined international immigration to Hawaii and the socio-economic status of the immigrants, with a focus on those from the Pacific Island nations. This research follows a thesis that the Hawaiian identify is one of change, inclusiveness and self-identification, and future generation Hawaiians' socio-economic status is affected by those who intermarry Hawaiians today.

Three factors underline the importance of this study. First, the fourth wave immigration has already had an impact in changing the racial and ethnic profiles of the U.S. population, significantly blurring racial lines [16, 23]. California, the largest state in the U.S., may serve as a good example. Between 1971 and 2000, California was the home state to a total of 4,528,307 immigrants (See Table 1), roughly $14 \%$ of its 33.8 million resident population in 2000. Because a large proportion of these immigrants were from Mexico, California's demographic profiles have greatly changed [24]. Hawaii is not an exception to mainland states. During the same time period from 1971 to 2000 , Hawaii took in a total of 216,440 immigrants, roughly $18 \%$ of its 2000 state population, an even larger proportion than California had. International immigration is thus assumed to have had at least some impact on Hawaii's population composition.

Second, in the last two decades Hawaii's domestic migration (population movement between Hawaii and other states) has been by and large negative, leaving international immigration the second most important source of population increase (after natural births) to the state. Third, intermarriage has been a norm in the islands, and all groups have high outmarriage rates, especially those of small sizes [1, 25]. As a result, the identity of a group, its culture and traditions have been mixed and diluted with those of others. Although this happens to all peoples in Hawaii, it concerns Native Hawaiians in a unique way, because they are the only indigenous people in the islands. Especially pertinent to this argument is the fact that Polynesians intermarry Hawaiians at a much higher rate than non-Polynesians.

Given these considerations, I tried to find support to the research thesis by asking four questions, to see if immigration will provide Pacific Islanders to Hawaii from the islands where ancestors of today's Hawaiians came, and if it does, to what a degree and possibly with what a socio-economic impact.

The findings of this study can be briefly summarized as follows: Hawaii receives more than its share of immigrants by size of state population, but on a declining trend over the years. Hawaii is also a lot more attractive to Pacific immigrants than other U.S. states, proportionately speaking.
However, the immigrants who chose to live in Hawaii have relatively lower occupational status than those who chose to live in other states. In addition, while the overall immigration to the U.S. has been increasing, the proportions that came from the Pacific and that went to live in Hawaii have both been declining over the years, so are the share of highstatus jobholders. The only exception to this trend is that the proportions of Pacific immigrants with professional and managerial jobs have been rather consistent, albeit only a small proportion of them came to live in Hawaii.

The potential impact of these patterns of immigration on Hawaii is complex. However, it might be estimated from several different angles. First, immigrants from the Pacific Island nations are a lot more likely to choose Hawaii as their home state than choosing to live on the mainland, especially among those from Samoa. Pacific islanders in Hawaii have had a higher probability of endogamy within the large racial/ethnic group referred to as Pacific Islanders [5]. Namely, Hawaiians are a lot more likely to marry Samoans than they would marry non-Pacific Islanders. This trend will to some extent provide outside sources of future Hawaiians.

Second, the immigrants who came to live in Hawaii tend to have lower socio-economic status as measured by occupational prestige. Their collective job status is also slightly lower than the state average, indicating that immigrants will not likely improve Pacific Islanders' socioeconomic status in the state.

Third, the proportions of all immigrants who came to Hawaii and those from the Pacific nations have been declining, so were the proportions of high-status jobholders. Although the percentage of Pacific immigrants with professional and managerial jobs has kept rather consistent, their small proportions among the total immigrants probably will not change the overall declining trend. Stated differently, Hawaii's immigrants are becoming less prepared over the years in terms of holding high status occupations. This trend will negatively affect future generation Hawaiians and other Pacific Islanders in the state.

Lastly, in spite of the patterns of Pacific immigration to Hawaii and their potential impact, the absolute number of immigrants from the Pacific nations to Hawaii is relatively very small. Over the 30 years from 1971 to 2000, only $5.25 \%$ of the total immigrants Hawaii received were from the Pacific. Their impact on Hawaii's Pacific Islanders (including Hawaiians) as summarized in the above three conclusions is therefore rather small, especially if the declining trend of immigration continues. In conclusion, contemporary immigration from the Pacific Island nations may only play a small role in shaping the racial, ethnic and socioeconomic profiles of the Pacific Islanders (and future generations of Hawaiians) in Hawaii. These profiles will largely be determined by Hawaii's internal population trends and social characteristics.

\section{REFERENCES}

[1] Schoen R, Barbara T. Intergroup marriage in Hawaii, 1969-1971 and 1979-1981. Soc Perspect 1989; 32(3): 365-82; Nordyke EC. The peopling of Hawaii. Honolulu, HI: University of Hawaii Press 1989; Fu X, Heaton TB. Status exchange in intermarriage among Hawaiians, Japanese, Filipinos and Caucasian in Hawaii: 19831994. J Comp Fam Stud 2000; 31(1): 45-61. 
[2] U.S. Bureau of the Census. Census SF1, Table DP-1 profiles of general demographic characteristics. Washington, DC: U.S. Government Printing Office 2000.

[3] Handy ES. Ancient Hawaiian civilization. Rutland, VT: Charles E. Tuttle Co. Publishers; 1965; Kuykendall RS, Grove DA. The Hawaiian Kingdom. In: Foundation and Transformation: Hawaii: A History. Honolulu, HI: University of Hawaii Press 1953; pp. 1778-854; Kodama-Nishimoto M, Nishimoto WS, Oshiro CA. Hanahana: An oral history anthology of Hawaii's working people. Honolulu, HI: University of Hawaii Press; 1984; Dudoit M, Ed. Kūnihi Ka Mauna (Steep Stands the Mountain). In: Volume 2: Ōiwi (a native Hawaiian journal) 2002 [Retrieved 11 Nov 2005]. Available from: http://www.Hawaii.edu/oiwi/about.html; Conklin KR. Are Kanaka Maoli Indigenous to Hawaii? [Online]. 2003, [cited 5 July 2005]. Available from: http://www.angelfire.com/hi2/ Hawaiiansovereignty/indigenous.html; Lee M. What is a Hawaiian? [Online]. 2005, [cited 29 July 2005]. Available from: http://us_asians.tripod.com/articles-Hawaiian.html.

[4] Elbert Samuel H. Internal relationships of polynesian languages and dialects. South West J Anthropol 1953; 9 (2): 147-73; Dudley, MK, Agard KK. A Call for Hawaiian Sovereignty. Honolulu, HI: Na Kane O, Ka Malo Press 1990; Dudoit M. Ed. Oia Mau Nō (We Go On). Volume 1. Ōiwi (a native Hawaiian journal) 1999 [Retrieved 30 July 2005]. Available from: http://www.Hawaii.edu/oiwi/about.html

[5] Smyser AA. Annexation caused tears of joy--and sadness. Honolulu Star-Bulletin, 1988.

[6] Fu X, Heaton TB. Interracial marriage in Hawaii: 1983-1994. Lewiston, NY: The Edwin Mellen Press 1997.

[7] Howard A. Hawaiians. In: Stephan Thernstorm, Ed. The Harvard Encyclopedia of American Ethnic Groups, Harvard University Press 1980; pp. 449-52; Stannard DE. Before the horror: the population of Hawaii on the eve of western contact. Honolulu, HI: University of Hawaii Press 1980.

[8] Buck E. Paradise remade. Philadelphia, PA: Temple University Press 1993; Lind AW. Hawaii's People. $4^{\text {th }}$ ed. Honolulu, HI: University of Hawaii Press 1980; Schmitt RC. Demographic Statistics of Hawaii: 1778-1965. Honolulu, HI: University of Hawaii Press 1968.

[9] Kitano HHL. Race relations. 4th Edition. Englewood Cliffs, NJ: Prentice Hall; 1991; Hawaii State Department of Business, Economic Development of Tourism. Hawaii State Data Book. Honolulu, HI: 1993-94; US Bureau of the Census. SF3, Table DP-2, Profiles of Selected Demographic Characteristics: 2000. Washington, DC: U.S. Government Printing Office 2000; Hawaii State Department of Health, Hawaii Health Surveillance Program. Hawaii State Data Book, special tabulation. Tables 1.17, 1.30 and 1.34. Honolulu, HI: 2000-2001.

[10] Peterson W. The classification of sub nations in hawaii: an essay in the sociology of knowledge. Am Soc Rev 1969; 34:863-87; Davis FJ. The Hawaiian alternative to the one-drop rule. In: Naomi Zack, Ed. American mixed race: the culture of microdiversity. rowman \&lLittlefield publishing Co.: 1995; pp. 121-37; Fu X. Impact of socioeconomic status on inter-racial mate selection and vivorce. Soc Sci J 2006; 43(3): 239-58.

[11] Adams RC. Interracial marriage in hawaii. Montclair, NJ: Patterson Smith 1969.

[12] US Bureau of the Census. Statistical Abstract of the United States. Washington, DC: U.S. Government Printing Office 1990.

[13] Hawaii State Department of Health. Hawaii State Data Book (Vital Statistics Supplement, Health Surveillance Program) Honolulu, HI: 1994-2000.
[14] Kritz M, Gurak DT. The American people: Census 2000immigration and a changing America. New York, NY: Russell Sage Foundation and Washington, DC: Population Reference Bureau 2004.

[15] Kivisto P. Multiculturalism in a global society. Malden, MA: Blackwell Publishing 2002.

[16] (a) Clark G, Ed. Portrait of America [online]. 2003, [cited 10 January 2005]. Available from: http://usinfo.state.gov/usa/infousa/facts/ factover/homepage.htm; Bean FD, Lee J, Batalova J, Leach M. Immigration and fading color lines in America. New York, NY: Russell Sage Foundation and Washington, DC: Population Reference Bureau; 2004.

[17] U.S. Bureau of the Census. Statistical abstract of the United States, $2004-2005$ (124 $4^{\text {th }}$ ed). Washington, DC: U.S. Government Printing Office 2005.

[18] US Bureau of the Census. 1\% public Use Micro-data Sample (PUMS). Washington, DC: U.S. Government Printing Office 2000.

[19] Greeley AM. Ethnicity in the United States: a preliminary Reconnaissance. New York, NY: Wiley 1974; Alba R. Ethnic identity: the transformation of white America. New Haven, CT: Yale University Press 1990; Gallagher C. Playing the ethnic card: how ethnic narratives maintain racial privilege. Paper presented at the 1990 Annual Meetings of the Southern Sociological Society; Atlanta, GA 1990.

[20] ICPSR. Inter-university Consortium for Political and Social Research [online]. 2004, [cited 31 January 2005]. Available from:http://www.icpsr.umich.edu/org/index.html

[21] Draper NR, Smith H, Eds. Applied regression analysis: Forecasting and control. San Francisco, CA: Holden-Day; 1981; Tiao GC, Reinsel GC, Pedrick JH, et al. A statistical trend analysis of ozonesonde data. J Geo Res 1986; 91(12, 13): 121-36.

[22] Reiss AJ, Jr. Occupations and social status. New York, NY: Free Press; 1961; Hodge RW, Siegal PM, Rossi PH. Occupational Prestige in the United States, 1925-1963. Am J Soc 1963; 70: 286-302; Blau PM, Duncan OD. The American occupational structure. New York, NY: Wiley 1967; Treiman DJ. Occupational prestige in Comparative Perspective. New York, NY:Academic Press 1977; National Opinion Research Center. General Social Surveys, 19721996: Cumulative Codebook. Chicago, IL: 1996; Gilbert D. American class structure: In an Age of Growing Inequality, $5^{\text {th }}$ ed. Belmont, CA: Wadsworth 1997.

[23] Martin P. Immigration and the changing face of rural America. Farm Foundation[online]. 2000, [cited 15 July 2005]. Available from: htpp//: www.farmfoundation.org/martin/martin.htm ; Fix ME, Passel JS. U.S. Immigration at the Beginning of the $21^{\text {st }} \mathrm{Cen}$ tury. Testimony before the U.S. House of Representatives Committee on the Judiciary, Subcommittee on Immigration and Claims [online], 2 Aug 2001, [cited Aug 28, 2004]. Available from: http//: www.urban.org/url.cfm?ID=9000417.

[24] Public Policy Institute of California. Who is your neighbor? Residential Segregation and Diversity in California (Volume 4 -1). San Francisco, CA: Sandoval JO, Johnson HP, Tafoya SM, 2002; Public Policy Institute of California. A state of diversity: demographic trends in California's regions(California Counts, Volume 3-5). San Francisco, CA: Johnson HP, 2002; Pew Hispanic Center. Unauthorized migrants: numbers and characteristics. Background briefing prepared for Task Force on Immigration and America's Future. Washington, DC: Passel J 2005.

[25] Schmitt RC, Rose CS. Marriage and divorce in Hawaii before 1870. Hawaii His Rev 1966; 1: 267-71; Hawaii State Department of Health. Marriage certificate data compilation file 1983-1994. Honolulu, HI 1995.

(C) Xuanning Fu; Licensee Bentham Open.

This is an open access article licensed under the terms of the Creative Commons Attribution Non-Commercial License (http://creativecommons.org/licenses/by-nc/3.0/) which permits unrestricted, non-commercial use, distribution and reproduction in any medium, provided the work is properly cited. 